\title{
MODERN METHODS OF BIODIESEL PRODUCTION: A REVIEW
}

\author{
Kwa Clovis Dze \\ Petroleum and Mining Training and Research Center \\ University of Douala, Cameroon
}

\begin{abstract}
Biodiesel is a clean alternative fuel to petrodiesel. This paper reviews the different methods of biodiesel production: pyrolysis, transesterification, Microemulsification and direct use. Many researches carried out to produce biodiesel continuously report that biodiesel is not competitive compared with petro-diesel due to the high cost of feedstock used for biodiesel production. Therefore, it is important that alternative production methods/feedstock be investigated.
\end{abstract}

Keywords - Biodiesel, Transesterification, petro-diesel, vegetable oils.

\section{INTRODUCTION}

Biodiesel is the monoalkyl ester of long fatty acids derived from renewable lipid feedstock such as vegetable oils and animal fats in a process called transesterification (reaction of triglycerides with an alcohol, mostly methanol, to produce fatty acid methyl esters (FAME) commonly referred to as biodiesel) for use in compression ignition (CI) engines Conley et al. (2006). According to Romano et al. (2011) biodiesel is mainly used as blends with petro-diesel and is denoted "Bx" where $\mathrm{x}$ is the percentage of biodiesel in the fuel. B100 therefore denotes pure biodiesel.

Biodiesel can be produced from edible, oils like palm, Soyabean, Rapeseed, and non-edible oils such as Pongamia, Jatropha, Mahua. it may also be produced from animal fat and marine algae Kumar et al. (2014).

\section{Benefits of Biodiesel}

The advantages relate to the use of biodiesel include

- Higher cetane number owing to its longer alkane chain

- It is a renewable fuel easily obtainable from vegetable oils and animal fats

- Higher solvency characteristics compared to petrodiesels

- Low toxicity, in comparison with diesel fuel.

- Completely biodegradable

- Lower Sulphur, nitrogen and metallic content which makes biodiesel much environmentally friendly (Gerpen et al. (2004); Knothe et al. (1997)).

\author{
Giyo Frederick Buyinda \\ Petroleum and Mining Training and Research Center \\ University of Douala, Cameroon
}

\section{Limitations of biodiesel.}

- Biodiesel is of lower energy content, approximately $8 \%$ less energy per gallon.

- Biodiesel has higher cloud and pour points. This implies it will freeze more rapidly than conventional diesel

- Biodiesel is not compatible with some metals and plastics such as hoses and gasket materials, this may cause them to soften, degrade, and rupture Conley et al. (2006).

The rest of the paper is organized as follows. The feedstock for biodiesel production is discussed in section II. The different methods for biodiesel productions discussed in section III. Physical and chemical properties of biodiesel are discussed in section IV and lastly Concluding remarks are given in section V.

\section{FEEDSTOCK FOR BIODIESEL PRODUCTION}

Biodiesel can be produced from a variety sources such as: vegetable oils, animal fats and marine algae. Table 1 below shows a list of the different oils used for production and the preferred catalyst, methanol ratio, temperature and yield.

Table-1: Feedstock for Biodiesel production $\underline{\operatorname{Moser}(2009)}$

\begin{tabular}{lllll}
\hline Feedstock & Catalyst & Methanol ratio & T/oC & Yield \\
\hline Jatropha & $\mathrm{KOH}$ & $5: 1$ & 60 & 99 \\
Waste cooking oil & $\mathrm{NaOH}$ & $9: 1$ & 60 & 90 \\
Rapeseed & $\mathrm{KOH}$ & $6: 1$ & 65 & 96 \\
Canola & $\mathrm{NaOH}$ & $6: 1$ & 40 & 93.5 \\
Cotton seed & $\mathrm{KOH}$ & $20: 1$ & 25 & 98 \\
Sunflower & $\mathrm{NaOH}$ & $6: 1$ & 60 & 97.1 \\
Palm & $\mathrm{NaOH}$ & $7: 1$ & 50 & 96 \\
Madhuca indica & Pseudomona apacia & $6: 1$ & 60 & 96 \\
\hline
\end{tabular}




\section{International Journal of Engineering Applied Sciences and Technology, 2020 \\ Vol. 5, Issue 5, ISSN No. 2455-2143, Pages 14-19 \\ Published Online September 2020 in IJEAST (http://www.ijeast.com)}

\section{PROCESS OF BIODIESEL PRODUCTION}

Biodiesel is mostly produced from vegetable oils (VO) and animal fats (AF). These oils were used in the past to power CI engines particularly in isolated areas where the supply of conventional fuel was becoming difficult but due to the modernization of the diesel engine these oils became unsuitable for direct use (Vrabie et al.( 2016); Sidibé et al., (2010)). Many transformation methods have been proposed aimed at rendering the oils better fuels for the CI engine as discussed below.

\section{Pyrolysis (cracking)}

Pyrolysis is the direct thermochemical decomposition of organic material at high temperatures in the absence of oxygen. The process is complex and consists of both simultaneous and successive reactions. In this process, thermal decomposition of organic components in biomass starts at $350{ }^{\circ} \mathrm{C}-550{ }^{\circ} \mathrm{C}$ and goes up to $700{ }^{\circ} \mathrm{C}-800{ }^{\circ} \mathrm{C}$. The long chains of carbon chains in biomass break down into smaller molecules in the form of gases, condensable vapors and solid charcoal under the pyrolysis conditions. However, the rate and extent of decomposition of biomass depends on the process parameters of the reactor such as temperature; pressure; reactor configuration; type of feedstock Jahiru et al. ( 2012). Pyrolysis can be catalytic or non-catalytic

\subsection{Thermal cracking}

The gross pyrolysis of saturated/unsaturated triglycerides (TG) at $300^{\circ} \mathrm{C}$ results in the formation of fatty acids (FA). At higher temperatures $400-500^{\circ} \mathrm{C}$ cracking of FA occur giving rise to short chain hydrocarbons (HC). A variety of reactions could be put to play to produce solid (char), liquid and gaseous fuels. Based on the reaction conditions, T, P, retention time and whether or not a catalyst is used, either diesel-based fuels or gasoline-based fuels are produced Oladeji et al. (2015).

\subsection{Catalytic cracking}

In the presence of catalysts such as transition metal catalysts or molecular sieve catalysts (activated alumina) the efficiency of conversion of TG to biofuels increases. Most commonly used catalysts for the pyrolysis of biomass include $\mathrm{NaOH}$ and $\mathrm{KOH}$ Mohamed et al. (2017).

\section{Micro-emulsification}

A micro-emulsion is a system of water, oil and amphiphile (surfactant + co-surfactant) in the liquid state having thermodynamic stability and isotropic property. The amphiphile is located at the boundary between oil and the aqueous phase giving the emulsion a definite microstructure with dimensions generally in the range 1-150nm Fangrui et al. (1999). They could be prepared from VO with an ester and dispersant or from $\mathrm{VO}+$ alcohol + surfactant + co-surfactant + cetane improvers. $\mu$-emulsions increase the spray characteristics of VO by explosive vaporization of the low boiling constituents in the micelles (Sandeep (2012); Ashish et al. (2014)). Alkyl nitrate is the most common cetane number improver added to vegetable oils. If micro emulsified diesel is used directly in a compression ignition engine, some problems arise such as incomplete combustion, carbon deposit, poor cold performance, dilution of lubricant and possibly nozzle failure Rajalingam et al. (2016).

\section{Direct use and blending}

In this method VO are mixed with diesel and used directly. This method remains archaic and very inefficient as it doesn't take into account the high viscosity, acid composition, free fatty acid content, as well as gum formation due to oxidation and polymerization during storage and combustion, carbon deposits and lubricant thickening on the performance of the CI engine and the emission properties Gebremariam et al. (2017).

\subsection{Transesterification (TransE)}

According to Schuchard et al. (1998), TransE is a chemical reaction where an ester is converted to another through the interchange of the alkoxy moiety when the original ester is made to react with an alcohol in the presence of a catalyst. In the process of biodiesel production, TransE (alcoholysis) Meher et al. (2004) is the chemical reaction between TG (esters of glycerol with three chains of paraffinic or olefinic free FA of variable lengths) and alcohol (mainly methanol) in the presence of a catalyst to produce monoalkyl esters and glycerol. The overall process is usually a sequence of 3-consecutive steps of reversible reactions Gónzalez et al. (2020). Though the stoichiometry of alcohol/TG is 3:1, an excess of alcohol is always needed. Based on the type of catalyst used different types of TransE processes result as discussed on the sections that follow

\subsubsection{Base-catalyzed transesterification}

In base catalyzed TransE, homogeneous catalysts such as $\mathrm{NaOH}, \mathrm{KOH}$ Arun et al. (2011), $\mathrm{NaOCH}_{3}, \mathrm{Na}_{2} \mathrm{CO}_{3}, \mathrm{~K}_{2} \mathrm{CO}_{3}$, $\mathrm{NaOCH}_{2} \mathrm{CH}_{3}$ could be used. The reaction proceeds by deprotonation of the alcohol by the base to produce an alkoxide and the protonated catalyst. The alkoxide then attacks the carbonyl group of the TG to form an alkyl ester and the corresponding anion of DG through a tetrahedral intermediate (TI). The same process repeats until all the TG is converted to a mixture of alkylesters and glycerol through DG and MG Jain et al. (2011). this is shown by Fig 1 above. Base catalysis is the most industrially employed TransE process. At the end of a homogeneously catalyzed base TransE, $\mathrm{H}_{3} \mathrm{PO}_{4}$ is often added to neutralize the base resulting in the production of vast quantities of undesired wastes. Also, the process is very sensitive to the presence of impurities like water and free fatty acids (FFA). This shortcoming is often overcome with the use of 


\section{International Journal of Engineering Applied Sciences and Technology, 2020 \\ Vol. 5, Issue 5, ISSN No. 2455-2143, Pages 14-19 \\ Published Online September 2020 in IJEAST (http://www.ijeast.com)}

heterogeneous catalysts (solid basic material) such as $\mathrm{MgO}$. Narasimharao et al. (2007). Figure 1 below shows the process of base catalyzed transE

Fig. 1. Mechanism of base-catalyzed TransE of VO. Schuchard et al. (1998).

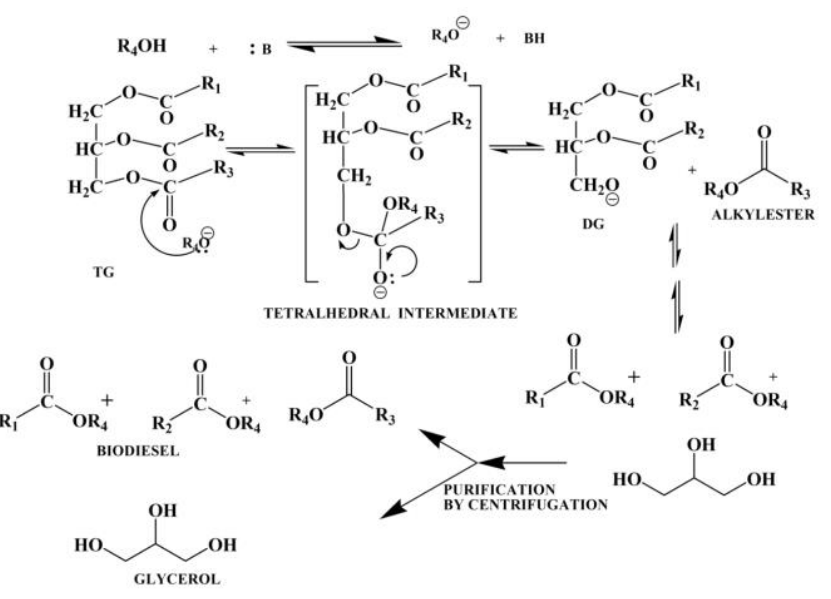

\subsubsection{Acid-catalyzed transesterification}

It is the second conventional method for biodiesel synthesis by TransE in the presence of a Bronsted acid like $\mathrm{H}_{2} \mathrm{SO}_{4}, \mathrm{HCl}$ or sulfonic acid $\left(\mathrm{RSO}_{3} \mathrm{H}\right)$, Parawira. W. (2010). This method is used when the VO has high FFA and $\mathrm{H}_{2} \mathrm{O}$ contents. The reaction proceeds by the protonation of the carbonyl group of the ester to produce a carbocation which after nucleophilic attack by the alcohol produces a TI which in turn eliminates glycerol to form the ester and regenerate the catalyst. Canakci et al. (1999) carried out an Acid-catalyzed transesterification and noted that it is much slower than alkali-catalyzed and that the ester conversion efficiency is strongly affected by the molar ratio of alcohol to oil. In acid-catalyzed esterification, a higher molar ratio is required than that of alkali-catalyzed. Fig 2 gives an illustration

\subsubsection{Enzyme-catalyzed Transesterification}

Lipases are enzymes that catalyze the hydrolysis and synthesis of a variety of acyl glycerols at interface of lipid and water. This method is not applied for the commercial production of biodiesels due to unfavorable retention time and reaction yields but remains a promising method for the synthesis of high purity biodiesel due to the regioselectivity and stereoselectivity of lipases. This could eradicate problems encountered in downstream processing of biodiesel such as separation of catalyst, unreacted methanol, glycerol recovery, removal of inorganic salts, risk of FFA and water contamination as well as soap formation, Venkates et al. (2014)

\subsubsection{Supercritical methanol transesterification}

Supercritical TransE is the non-catalytic synthesis of biodiesel from methanol and TG at a $\mathrm{T}$ and $\mathrm{P}$ above the critical point of the mixture. The reaction mechanism is the same as that of acidcatalyzed in that the $\mathrm{H}$-bond of methanol is weaken at high temperatures $\left(>200^{\circ} \mathrm{C}\right)$ to form a free alcohol monomer which directly attacks the carbonyl carbon of the TG or FFA to form a TI which then decomposes to produce the methylester. The shortcoming of this method is the high cost of production due to the use increased $\mathrm{T}$ and $\mathrm{P}$ which also contribute to the high temperature degradation of the FAME formed (Silva et al. (2014; Somkiat et al. (2011)).

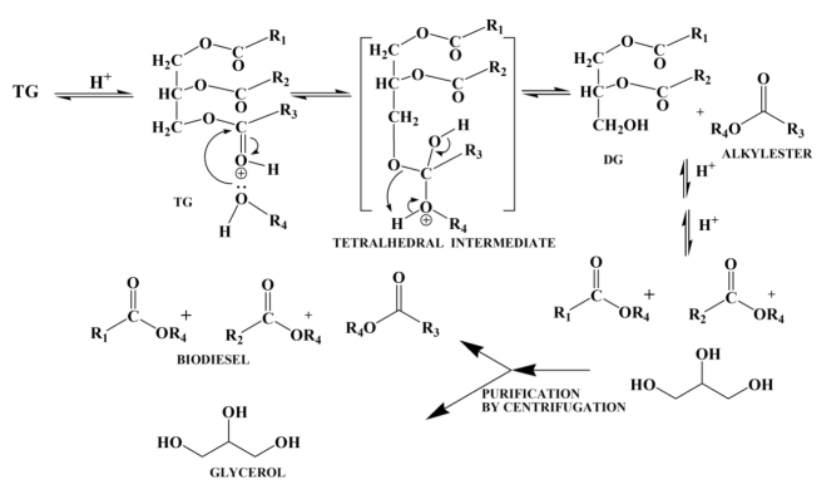

Fig. 2. Mechanism of acid-catalyzed TransE of TG. Ejikeme et al. (2009)

\subsubsection{Conclusion}

There are basically four different methods for the production of biodiesel nanmely; Microemulsification, direct use and blending, pyrolysis and transesterification. The section that follows throws more light on the physical and chemical properties of biodiesel.

\section{PROPERTIES OF BIODIESEL PRODUCED FROM DIFFERENT FEEDSTOCKS}

\subsection{Physical properties}

The important physical properties of biodiesel form any given source include; density, kinematic viscosity, flash point, cloud point, pour point, specific gravity Ved et al. (2013). According to the study carried out by Thangapandian et al. (2015), the properties of biodiesel greatly depend on the feedstock used, this is further substantiated by table 2 below.

Table-2: physical properties of biodiesel from various feedstock 


\begin{tabular}{|c|c|c|c|c|c|}
\hline Feedstock & Density $(\mathrm{Kg} / \mathrm{m} 3)$ & $\mu(\mathrm{mm} 2 / \mathrm{s})$ & Flash point $/ 0 \mathrm{C}$ & Pour point & References \\
\hline Diesel & 850 & 2.6 & 68 & -20 & Parawira et al. (2010) \\
\hline Biodiesel & 880 & 4.29 & 182 & -8 & Jun et al. (2017) \\
\hline Jatropha & 880 & 4.8 & 135 & 2 & Parawira et al. (2010) \\
\hline Waste cooking oil & 920 & 2.88 & $\ldots$ & -12 & Pati et al. (2014) \\
\hline Rapeseed & 930 & 4.56 & $\ldots$. & -15 & Azocar et al. (2016) \\
\hline Canola & 880 & 4.51 & 110 & -5 & Fan et al. (2009) \\
\hline Cotton seed & 874 & 4.27 & 142 & -15 & Madiwale et al. (2017) \\
\hline Sunflower & 870 & 1.9 & 183 & 1 & Thirumarimurugan et al. (2012) \\
\hline Palm & 874.8 & 4.452 & 135 & 12.1 & Borhanipour et al. (2014) \\
\hline
\end{tabular}

\subsection{Chemical properties}

From the studies carried out by Okullo et al. (2012) on the transesterification of jatropha and castor oils and AnguebesFranseschi et al. (2019) on the transesterification of sailfin catfish biomass oil, the reported the most commonly studied chemical properties of biodiesels. These are; cetane number, metallic content, fatty acid composition, water content, ash content, acid content, calorific value, iodine index, peroxide index. Table 3 below gives a list of different oil feedstocks and their chemical properties. Whatever the starting feedstock and the choice of catalyst, the process of biodiesel production can be summarized as shown on figure 3 below Marchetti et al. (2007)

Table-3: chemical properties of biodiesel from different

\begin{tabular}{|c|c|c|c|c|c|c|}
\hline Feedstock & $\begin{array}{l}\text { Water } \\
\text { content } \\
(\%)\end{array}$ & $\begin{array}{l}\text { Ash } \\
\text { content } \\
(\%)\end{array}$ & $\begin{array}{l}\text { Carbon } \\
\text { residue } \\
(\%)\end{array}$ & $\begin{array}{l}\text { Acid } \\
\text { value } \\
\text { (mgKOH/g) }\end{array}$ & $\begin{array}{l}\text { Calorific } \\
\text { value } \\
(\mathrm{MJ} / \mathrm{Kg})\end{array}$ & References \\
\hline Diesel & 0.02 & 0.01 & 0.17 & $\ldots$ & 42 & Parawira et al. (2010) \\
\hline Biodiesel & $<0.05$ & 0.01 & 0.05 & 0.5 & 39.48 & Hoekman et al. (2011) \\
\hline Jatropha & 0.025 & 0.012 & 0.20 & 0.40 & 39.23 & Parawira et al. (2010) \\
\hline Waste cooking oil & 0.033 & $\ldots$ & $\ldots$ & $\ldots$. & 44.4 & Pati et al. (2014) \\
\hline Rapeseed & 0.031 & $\ldots$ & $\ldots$ & 0.77 & $\ldots$. & Azocar et al. (2016) \\
\hline Canola & $<0.05$ & 0.09 & $<0.05$ & 0.14 & $\ldots$ & Chhetri et al. (2012) \\
\hline Cotton seed & 0.52 & $\ldots$ & $\ldots$ & 0.3 & 36.8 & Eevera et al. (2013) \\
\hline Sunflower & $\ldots$ & $\ldots$ & $\ldots$. & 0.5 & 33.5 & Cervero et al. (2008) \\
\hline Palm & 0.0297 & $\ldots$ & $\ldots$ & 0.115 & 39.9 & Borhanipour et al. (2014) \\
\hline
\end{tabular}

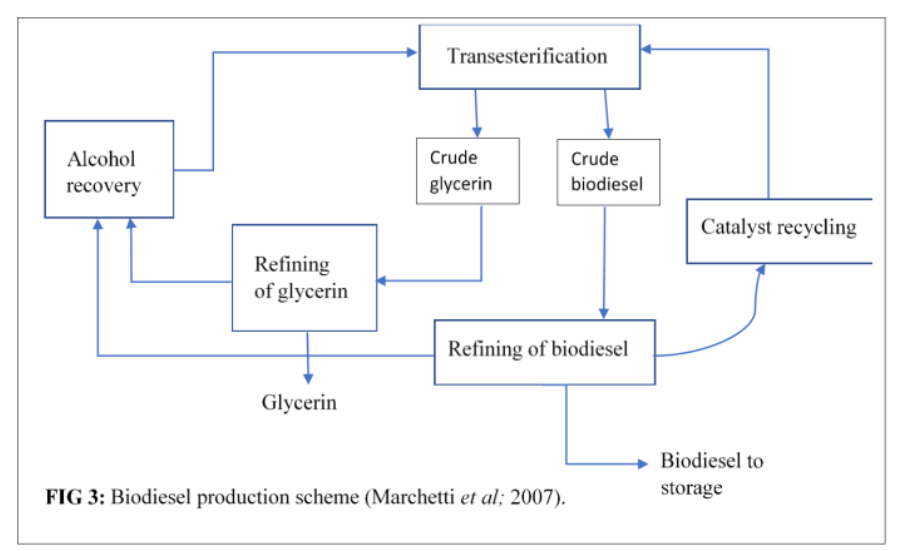

\section{CONCLUSION}

The objective of this study was to review the different methods currently employed for biodiesel production. Currently there are four methods that are used: pyrolysis, direct use/blending, Microemulsification and transesterification (acid-catalyzed, base-catalyzed, enzyme-catalyzed and supercritical methanol transesterification). Different feedstocks such as; jatropha, canola, sunflower, palm, cotton seed rapeseed and waste cooking oils are used. Most of the researches reviewed indicate that biodiesel is mostly produced by the process of transesterification using vegetable oils as feedstock. However, the production of biodiesel from any of the vegetable oils is uneconomical due to the high prices of these oils. It is therefore important that, alternative production schemes requiring low cost feedstock be investigated.

\section{REFERENCES}

[1] Anguebes-Feanseschi F., Bassam. A., Abatal M., Tzuc M.O., Aguilar-Ucan c., Kusukoki A.T.W. (2019). Physical and Chemical Properties of Biodiesel Obtained from Amazon Sailfin Catfish (Pterygoplichthys pardalis) Biomass Oil.Journal of Chemistry 12. https://doi.org/10.1155/2019/7829630.

[2] Arun N., Sampath M., Siddharth S., Prasaanth R.A. (2011). Studies of base catalyzed transesterification of karanja oil. International Journal of Energy and Envirionment 2 (2): 351-356.

[3] Ashish, D.G. and Jyotsona, T.W. (2014). A Short Review on Microemulsions and its Applications in Extraction of Vegetable oils. International Journal of Research in Engineering and Technology 03 (09): 147-158.

[4] Azocar L.., Erick S., Hidalgo P., Betancourt R., Navia R. (2016). Biodiesel Production From Rapeseed Oil with Waste Fring Oils. Frontera: Ph.D. Program in Sciences of Natural Resources, Universidad de La Frontera.

[5] Borhanipour, M., Karin, P., Tongroon, M., Chollacoop, N., Hanamura, K. (2014). Comparison Study on Fuel Properties of Biodiesel from Jatropha, Palm and Petroleum-based Diesel Fuel. SAE Technical Paper nd. doi: 10.13140/2.1.1027.9044.

[6] Canakci, M., Van Gerpen J. (1999). Biodiesel Production via Acid Catalysis. American Society of Agricultural Engineers 42 (5): 1203-1210.

[7] Cerveró J.M., Coca J. and Luque s. (2008). Production of biodiesel from vegetable oils. (GRASAS Y ACEITES) 59 (1): 76-83.

[8] Chhetri, A. B., \& Watts, K. C.(2012). Densities of canola, jatropha and soapnut biodiesel at elevated temperatures and pressures. Fuel 99(7): 210-216. doi:10.1016/j.fuel.2012.04.030 . 


\section{International Journal of Engineering Applied Sciences and Technology, 2020 \\ Vol. 5, Issue 5, ISSN No. 2455-2143, Pages 14-19 \\ Published Online September 2020 in IJEAST (http://www.ijeast.com)}

[9] Conley, Tao S.P, and B. 2006. "What is Biodiesel. Bioenerfy-Purdue University.

[10] Da Silva, C., Vladimir, J.O. (2010). Biodiesel Production through non Catalytic Supercritical Transesterification: Current State and Perspectives. Brazilian Journal of Chemical Engineering 31 (02): 271-285.

[11] Eevera T., and Pazhanichamy K. (2013). Cotton Seed Oil: A Feasible Oil Source for Biodiesel. (Energy Sources) 35 (12): 1118-1128. doi: 10.1080/15567036.2010.514648.

[12] Ejikeme, P.M., Anyaogu, I.D., Ejikeme, C.L., Nwafor, N.P. (2010). Catalysis in Biodiesel Production by the Transesterification Processes-An Insight. E-Journal of Chemistry 7 (4): 1120-1132.

[13] Fan X., Burton R., Austic G. (2009). Preparation and Characterization of Biodiesel Produced from Recycled Canola Oil. The Open Fuels \& Energy Science Journal 2(1): 113-118.

[14] Fangrui M., Hanna M.A. (1999). Biodiesel Production: A Review. Bioresource Technology (Elsevier) 70: 1-15.

[15] Gashaw A., Teshita A.N. (2014). Production of biodiesel from waste cooking oil and factors affecting its formation: A review. International Journal of Renewable and Sustainable Energy 3(5): doi:10.11648/j.ijrse.20140305.12.

[16] Gebremariam S.N., Marchetti J.M. (2017). Biodiesel production technologies: A Review. Energy 5 (3): 425457. doi:10.3934/energy.2017.3.425.

[17] Gerpen V.J., Shanks B., Pruszko R., Clements D., Knothe G. (2004). Biodiesel Production Technology. National Renewable Energy laboratory. https://www.nrel.gov/docs/fy04osti/36244.pdf

[18] Gónzalez J.P.C., Gutiérrez P.E.A., Medina M.A., Zapata B.Y.L., Guerrero G.V.R., Valdés 1.G.V. (2020). Effects on Biodiesel Production Caused by Feed Oil Changes ina Continuously Stirred Tank Reactor. Applied Sciences 10: 1-24. doi:10.3390/app10030992.

[19] Hoekman, S.K., BrochA., Robbins C., Ceniceros E., ManiNatarajan. (2011). Review of biodiesel composition, properties, and specifications. Renewable and Sustainable Energy Reviews 16: 143-169.

[20] Jahirul M.I., Rasul M.G., Chowdhury A.A., Ashwath N. (2012). Biofuels Production through Biomass Pyrolysis: A Review. Energies 5: 4952-5001. doi:10.3390/en5124952.

[21] Jain S., Sharma M.P., Rajvanshi S. (2011). Acid base catalyzed transesterification Kinetics of Waste Cooking Oils. Fuel Processing Technology 92: 32-38.

[22] Jun C.G., Yoon S.K., Choi N.J. (2017). Using Canola Oil Biodiesel as an Alternative Fuel inDiesel Engines: A Review. Applied Science 1-19.

[23] Knothe G., Dunn RO., Bagby M.O. (1997). Biodiesel: the use of Vegetable oils and their Derivatives as Alternative Diesel Fuels. $2^{\text {nd }}$ Edition. New York: American Chemical Society.
[24] Kumar, and Sharma, MP., and Dwivedi G. P. (2014). Impact of Biodiesel on Combustion, performance and Exhaust Emissions of Diesel Engines. Journal of Integrated Science \& Technology 2 (2): 57-63.

[25] Madiwale S., Karthikeyan A., Bhojwani V., Chougule S. (2017). Cottonseed Oil Biodiesel With Ethanol as an Additive-An. ARPN Journal of Engineering and Applied Sciences 12 (17): 5160-5167.

[26] Meher L.C., Sagar D.V., Naik. S.N.. (2006). Technical Aspects of Biodiesel Production by Transesterification-A Review. Renewable and Sustainable Energy Reviews 10: 248-268. doi:10.1016/j.rser.2004.09.002.

[27] Mohamed M.A., Hashim A.M., Abu-Elyazeed O.S.,. (2017). Biofuel Production from Used Cooking Oil Using Pyrolysis Process. International Journal for Research in Applied Science \& Engineering Technology 5 (11): 29712976.

[28] Moser B.R. (2009). Biodiesel production, properties, and feedstocks. The Society for In Vitro Biology, 45: 229-266. doi:10.1007/s11627-009-9204-z.

[29] Narasimharao, K.A., Wilson, K., Lee, A.F. (2007). Catalysis in the Production of Biodiesel: A Review. Journal of Biobased Materials and Bioenergy 1: 112.Okullo A., Temu A.K., Ntalikwa JW. (2012). PhysicoChemical Properties of Biodiesel fromJatropha and Castor Oils. International Journal of Renewable Energy Research 2 (1): $1-5$.

[30] Oladeji, J.T., Itabiyi E.A., Okekunle P.O. (2015). A Comprehensive Review of Biomass Pyrolysis as a Process of Renewable Energy Generation. Journal of Natural Science Research 5 (5): 99-105.

[31] Parawira, W. (2010). Biodiesel Production from Jatropha Curcas. A Review. Scientific Research and Essays 5 (4): 1796-1808.

[32] Patil D. P., Cude V.G., Reddy H.K, Muppaneni T., Deng S. (2012). Biodiesel Production from Waste Cooking Oil Using Sulfuric Acid and Microwave Irradiation Processes. (Journal of Environmental Protection) 3: 107-113. doi:10.4236/jep.2012.31013.

[33] Peterson C.L., Reece D.L., Hammond B.L., Thompson J., Beck S.M. (1997). Processing, Characterisation and Performance of Eight Fuels from Lipids. Applied Engineering in Agriculture, 13 (1). doi:10.13031/2013.21578.

[34] Rajalingam ., Jani S.P., Kumar A.S., Khan M.A.,. (2016). Production methods of biodiesel. Journal of Chemical and Pharmaceutical Research 8 (3): 170-173.

[35] Romano, and Sorichette, P.A. S.D. (2011). Dielectric Spectroscopy in Biodiesel production. Green Energy and Technology 27-33.

[36] Sandeep, S. (2012). Study of Various Methods of the Biodiesel Production and Properties of Biodiesel from 


\section{International Journal of Engineering Applied Sciences and Technology, 2020 \\ Vol. 5, Issue 5, ISSN No. 2455-2143, Pages 14-19 \\ Published Online September 2020 in IJEAST (http://www.ijeast.com)}

Waste Cotton Seed Oil and waste Mustard Oil. Master's Thesis of the Thapar University, India.

[37] Schuchard, U.S., Sercheli, R., Vargas, R.M. (1998). Transesterification of Vegetable Oils: a Review. Journal of Brazilian Chemical Society 9 (1): 199-210.

[38] Sidibé, S.S., Blin, J., Vaitilingom, G., Azoumah, Y. (2010). Use of Crude Filtered Vegetable Oil as a Fuel in Diesel Engines State of the Art: A Review. Renewable and Sustainable Energy Reviews-Elsevier 3: 2748-2759.

[39] Somkiat, N., Ruengwit, S. (2011). Transesterification in Supercritical conditions. Feedstock and Processing Technology. First Edition.

[40] Thangapadian E., Lucas J. (2015). Biodiesel and its Properties from Various Feedstocks. International Journal for trends in Engineering and Technology 1 (1).

[41] Thirumarimurugan M., Sivakumar V.M., Merly Xavier A., Prabhakarand., Kannadasan T. (2012). "Preparation of Biodiesel from Sunflower Oil by Transesterification. International Journal of Bioscience, Biochemistry and Bioinformatics, 2 (6): 441-444.

[42] Ved K., Padam K.,. 2013. Study of Chemical and Physical Properties of Biodiesel from Sorghum oil. Research Journal for Chemical Sciences 3 (9): 64-68.

[43] Venkateswarulu, T.C., Raviteja, C.V., Prabhaker, K.V., Babu, D.J., Indira, M. (2014). A Review of the Methods of Transesterification of Oils and Fats in Biodiesel Formation. International Journal of ChemTech Research 6 (4): 25682576.

[44] Vrabie, V., Scarpete, D., Zbarcea, O. (2016). Vegetable Oils as Alternative Fuels for new Generation of Biodiesel Engines: A Review. cientific Proceedings. International Scientific-Technical Conference 105-109.

\section{ACKNOWLEDGEMENT}

I express my heartfelt gratitude to Pr. AZEBAZE Anatole Guy Blaise of the Department of Chemistry University of Douala who was kind enough to spare time from his busy schedule to go through this paper. His criticisms, suggestions and encouragements have contributed so fundamentally to the development of this article

I express my deep sense of gratitude to Mr. HAMENI HAKOUA Yves, manager of the mechanical maintenance Department, DPDC for his discussion and suggestions on various aspects of the subject

I sincerely thank Dr. Balamourougane of LEAD College of Management, Dhoni, Palakkad India for his encouragements and directives on various aspects on the format of a research paper 